\title{
Serum Hepcidin and Prohepcidin Levels in Nonfebrile and Febrile Neutropenia
}

\author{
Basak Unver Koluman ${ }^{1}$, Esin Avci $^{2}$, Nil Guler ${ }^{1}$, Gulsum Akgun Cagliyan ${ }^{1}$ and Hande Senol ${ }^{3}$ \\ ${ }^{1}$ Department of Hematology, Medical Faculty of Pamukkale University, Denizli, Turkey \\ ${ }^{2}$ Department of Medical Biochemistry, Medical Faculty of Pamukkale University, Denizli, Turkey \\ ${ }^{3}$ Department of Biostatistics, Medical Faculty of Pamukkale University, Denizli, Turkey
}

\begin{abstract}
Objective: To compare the prohepcidin and hepcidin levels in the afebrile neutropenic period and neutropenic fever in patients with hematological malignancy.

Study Design: Descriptive study.

Place and Duration of Study: Department of Hematology, Pamukkale University Hospital, Denizli, Turkey, between January 2018 and December 2019.

Methodology: Neutropenic patients were compared with a healthy control group. Prohepcidin and hepcidin serum levels were to be measured in neutropenic and control groups. When fever occurred in neutropenic group, serum was taken again and the same values were compared, in addition to procalcitonin and CRP values.

Results: Prohepcidin and hepcidin levels were found to be significantly higher in the neutropenic group ( $\mathrm{n}=53$ ) than the control group [ $\mathrm{n}=44$, (med:166.65 ng/ml, IQR:147.66 - $187.38 \mathrm{ng} / \mathrm{ml} v \mathrm{~s}$. med:47.49 ng/ml, IQR:15.61 - 82.51 ng/ml; p <0.001); (med:315 ng/ml, IQR:314.92 - $315 \mathrm{ng} / \mathrm{ml}$ vs. med:26.61 ng/ml, IQR:4.69 - $66.83 \mathrm{ng} / \mathrm{ml} ; \mathrm{p}<0.001$ )]. No significant difference was found in terms of these two analyses $(167.29 \pm 29.31 \mathrm{ng} / \mathrm{ml}$ vs. $167.15 \pm 27.61 \mathrm{ng} / \mathrm{ml} ; \mathrm{p}=0.979 ; 296.21 \pm 37.19 \mathrm{ng} / \mathrm{ml}$ vs $299.16 \pm 37.68 \mathrm{ng} / \mathrm{ml} ; \mathrm{p}=0.629$ ) in the neutropenic fever period compared to the afebrile neutropenic period. In neutropenic fever patients, procalcitonin and CRP (C-reactive protein) were found significantly higher than the afebnile neutropenic group $(0.7 \pm 1.2 \mathrm{ng} / \mathrm{ml}$ vs. $0.25 \pm 0.76 \mathrm{ng} / \mathrm{ml} ; \mathrm{p}=0.034 ; 10.27 \pm 9.93 \mathrm{mg} / \mathrm{dl}$ vs $2.61 \pm 2.78 \mathrm{mg} / \mathrm{dl} ; \mathrm{p}<0.001)$.

Conclusion: Although there was no significant difference between afebnile neutropenia and neutropenic fever in patients in terms of hepcidin and prohepcidin levels, higher levels were found in both groups compared to the control group.
\end{abstract}

Key Words: Hepcidin, Prohepcidin, Neutropenia, Febrile neutropenia.

How to cite this article: Koluman BU, Avci E, Guler N, Cagliyan GA, Senol H. Serum Hepcidin and Prohepcidin Levels in Nonfebrile and Febrile Neutropenia. J Coll Physicians Surg Pak 2021; 31(11):1303-1307.

\section{INTRODUCTION}

Febrile neutropenia is an emergency and life-threatening complication, especially in patients with chemotherapy-induced neutropenia. ${ }^{1}$ Febrile neutropenia can occur at any time during a malignancy, from diagnosis to end-stage disease. ${ }^{2}$ Infection focus should be controlled with appropriate antibiotic treatment immediately. The type of antibiotic treatment, how long, and how it will be given is determined according to the patient's risk group. If febrile neutropenia is not controlled in time, it may progress to sepsis. Sepsis is a significant reason for mortality during neutropenia of malignancies. Thus, early diagnosis and urgent management are essential. ${ }^{3}$

Correspondence to: Dr. Basak Unver Koluman, Department of Hematology, Medical Faculty of Pamukkale

University, Denizli, Turkey

E-mail: bkoluman@pau.edu.tr

Received: June 01, 2021; Revised: September 20, 2021;

Accepted: October 15, 2021

DOI: https://doi.org/10.29271/jcpsp.2021.11.1303
Iron is an essential element for nearly all organisms. Iron and its homeostasis are closely related to the inflammatory response. ${ }^{4}$ Inflammation results in an elevated serum ferritin level as a part of the acute-phase response, blockage of tissue iron release, decreased serum iron, and total iron-binding capacity. This response is suggested to be mediated by inflammatory cytokines. ${ }^{5}$ In the end, an acute hypoferremia occurs, inhibiting pathogen proliferation and growth. ${ }^{6}$

In recent years, the hepcidin molecule, which is thought to play a critical role in iron metabolism, has been focused on ${ }^{7,8}$ It is synthesised in hepatocytes in the liver, but it can be found in mature form or as a form of a prohormone in the blood. ${ }^{9}$ This peptide is obtained from the C-terminal of an 84 amino acid prepropeptide. ${ }^{10}$ Subsequently, prohepcidine containing 60 amino acids occurs. Prohepcidin is an essential marker for providing information for the evaluation of inflammation. ${ }^{11,12}$ The protein of prohepcidin is converted to hepcidin with the enzyme furin convertase. ${ }^{13}$ Hepcidin reduces the absorption of duodenal iron, prevents the release of macrophage iron, and regulates iron balance by reducing iron in the organism. 
Hepcidin is also considered an acute-phase protein, and its synthesis is induced by IL-6 (interleukin 6). ${ }^{11}$ It is known that inflammation increases hepatic mRNA levels of hepcidin. ${ }^{14}$ In the case of inflammation, hepcidin levels increase, and iron is retained by macrophages and liver cells and absorbed from the intestines, thereby decreasing serum iron levels. The production of hepcidin in hepatocytes is indirectly regulated by the infection and the level of iron. Hepcidin is also an antimicrobial protein. In the case of infection, fever is an inflammatory response created by the body. In neutropenic fever, hepcidin via ferroportin (the receptor of hepcidin) prevents pathogens from taking iron and contributes to host defence. ${ }^{15}$ This raises the question of whether hepcidin may be utilised as a follow-up measure in neutropenic individuals who develop fever?

There are very few studies investigating the interactions between hepcidin and neutropenic patients with hematologic malignancy. However, to the best of authors' knowledge, there is no data on this interaction in adult neutropenic hematology patients. It was intended to assess the levels of hepcidin and prohepcidin in neutropenia and neutropenic fever, if it might be utilised as a monitoring parameter in these cases.

The aim was to compare prohepcidin and hepcidin in neutropenic and neutropenic feverperiods.

\section{METHODOLOGY}

Neutropenic patients, who were hospitalised in the hematology service at the Department of Hematology, Pamukkale University Hospital, Denizli, Turkey, between 2018-2019 due to hematological malignancy and healthy control subjects were included in the study.

Neutropenia was defined as an absolute neutrophil count of less than 1500/ $\mu$ in neutropenic patients with hematological malignancies. Patients were diagnosed with 'neutropenic fever as described in the ESMO guidelines. Serum levels of prohepcidin and hepcidin were investigated in the neutropenic and control groups; and during fever, the neutropenic group, again. Neutropenic fever was defined as an absolute neutrophil count of $<500 / \mu \mathrm{l}$, and oral temperature $>38.3^{\circ} \mathrm{C}$ or two consecutive $>38.0^{\circ} \mathrm{C}$ for at least two hours. Patients were questioned for complaints; the physical examination was performed to focus on infection, and cultures were sent from possible foci. The results of culture were obtained from HIS (hospital information system).

Fasting venous blood samples were collected in the morning, and demanded from the participants of neutropenic and control groups. When fever developed, venous blood samples were collected again. Serum obtained by the centrifugation of the blood samples was aliquoted and stored in $-20^{\circ} \mathrm{C}$ until serum hepcidin and prohepcidin levels were measured. Complete blood count results, CRP (0-0.5 ug/dl), ferritin (13- $150 \mathrm{ug} / \mathrm{L}$ for female, 30-400 ug/L for male), and pro-calcitonin levels ( $<0.5$ $\mathrm{ng} / \mathrm{ml}$ ) were measured the same day when the samples obtained. Serum hepcidin (Cusabio Technology LLC, USA) (ng/ml) and prohepcidin (Cusabio) (ng/ml) levels were measured by using commercial kits, according to the manufacturer's instructions. All these two parameters were measured by the enzyme-linked immunosorbent method.

All statistical analyses were performed using SPSS version 25.0 [IBM SPSS Statistics 25 software (Armonk, NY: IBM Corp.)]. The mean \pm standard deviation defined continuous variables, and categorical variables were defined by number and percent. Shapiro-Wilk test was used for the determination of normal distribution. For dependent group comparisons, paired samples t-test was used when parametric test assumptions were provided; and Wilcoxon signed rank test was used, otherwise. Mann-Whitney U-test was used in comparison with the control group. Spearman correlation analysis was used for analysing the relationships between continuous variables. Statistical significance was determined as $p<0.05$.

\section{RESULTS}

Fifty three patients diagnosed with hematological malignancy (21 women, (39.6\%) and 32 men, 60.4\%) were included in the study. The mean age of the patients included in the study was $58.09 \pm 16.84$ years. The majority of the patients had AML ( 31 , $58.5 \%)$. There were five cases of multiple myeloma, 4 cases of myelodysplastic lymphoma, three cases of ALL (acute lymphoblastic leukemia) and diffuse large B cell lymphoma, and one case each of follicular lymphoma, Hodgkin lymphoma, mantle cell lymphoma, peripheral T cell lymphoma, central nervous system lymphoma, biphenotypic leukemia, and CLL (chronic lymphocytic leukemia).

In 39 patients (73.6\%), neutropenic was secondary to chemotherapy, and 14 patients $(26.4 \%)$ were neutropenic due to hematological malignancy itself. The average absolute neutrophil count of the included neutropenic patient group was

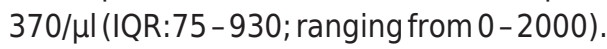

During the neutropenic fever period, the average body temperature was $38.4 \pm 0.41^{\circ} \mathrm{C}$. Vital signs were stable in most patients during neutropenic fever. Only hypotension occurred in two patients, tachycardia in five patients, and tachypnea and hypoxia occurred in one patient each during neutropenic fever.

Microorganism isolation (37.7\%) was achieved in some of the taken cultures. Isolation was primarily obtained from blood cultures (12 patients). In addition, growth of pathogenic microorganism (data not shown) growth was recorded in the sputum culture of four patients, in the urine culture of three patients, and in the catheter culture of one patient.

Prohepcidin and hepcidin were found to be significantly higher in the neutropenic group than the control group [(med: 166.65 ng/ml, IQR: $147.66-187.38 \mathrm{ng} / \mathrm{ml}$ vs. med: $47.49 \mathrm{ng} / \mathrm{ml}$, IQR: $15.61-82.51 \mathrm{ng} / \mathrm{ml} ; \mathrm{p}=0.0001$ ); (med: $315 \mathrm{ng} / \mathrm{ml}$, IQR: 314.92 $315 \mathrm{ng} / \mathrm{ml}$ vs. med: $26.61 \mathrm{ng} / \mathrm{ml}$, IQR: $4.69-66.83 \mathrm{ng} / \mathrm{ml} ; \mathrm{p}$ $<0.001$, respectively)]. No significant correlation was found neither between prohepcidin and the iron parameters [ferritin $(r$ $=-0.074 ; p=0.677)$, serum iron level $(r=-0.234 ; p<0.140)$ and transferrin saturation $(r=-0.229 . p=0.200)$ ] nor between 
hepcidin and the iron parameters [ferritin ( $r=-0.111 ; p=0.527)$, serum iron level $(r=-0.111 ; p=0.482)$ and transferrin saturation $(r=-0.195 ; p=0.269)]$ in the neutropenic group (Tablel).

Table I: Relationship of iron parameters with prohepcidin, hepcidin and CRP in neutropenic patients.

\begin{tabular}{|c|c|c|c|c|}
\hline & $\begin{array}{c}\text { Ferritin } \\
(\mu \mathrm{g} / \mathrm{l})\end{array}$ & $\begin{array}{c}\text { Serum Iron } \\
(\mu \mathrm{g} / \mathrm{dl})\end{array}$ & $\begin{array}{c}\text { TIBC** } \\
(\mu \mathrm{g} / \mathrm{dl})\end{array}$ & TS***(\%) \\
\hline $\begin{array}{l}\text { Prohepcidin }(\mathrm{ng} / \mathrm{ml}) \\
\mathrm{r} \\
\mathrm{p}\end{array}$ & $\begin{array}{r}-0.074 \\
0.677\end{array}$ & $\begin{array}{c}-0.234 \\
0.140\end{array}$ & $\begin{array}{l}0.136 \\
0.449\end{array}$ & $\begin{array}{l}-0.229 \\
0.200\end{array}$ \\
\hline $\begin{array}{l}\text { Hepcidin (ng/ml) } \\
r \\
p\end{array}$ & $\begin{array}{l}-0.111 \\
0.527 \\
\end{array}$ & $\begin{array}{c}-0.111 \\
0.482 \\
\end{array}$ & $\begin{array}{l}0.125 \\
0.481 \\
\end{array}$ & $\begin{array}{l}-0.195 \\
0.269 \\
\end{array}$ \\
\hline $\begin{array}{l}\text { CRP (mg/dl) } \\
r \\
p\end{array}$ & $\begin{array}{l}0.242 \\
0.122\end{array}$ & $\begin{array}{l}-0.115 \\
0.413\end{array}$ & $\begin{array}{c}-0.334 * \\
0.033\end{array}$ & $\begin{array}{c}-0.319 * \\
0.042\end{array}$ \\
\hline
\end{tabular}

Table II: Comparison of prohepcidin, hepcidin and CRP in neutropenic period and neutropenic fevergroups.

\begin{tabular}{|l|c|c|c|}
\hline & $\begin{array}{c}\text { Neutropenic } \\
\text { period }\end{array}$ & $\begin{array}{c}\text { Neutropenic } \\
\text { fever period }\end{array}$ & \multirow{2}{*}{ p-value } \\
\cline { 2 - 3 } & Med (IQR) & Med (IQR) & \\
\hline Hemoglobin $(\mathrm{g} / \mathrm{dL})$ & $8.4(7.7-9.7)$ & $8.3(7.4-8.95)$ & $0.483 \beta$ \\
\hline White blood cell $(\mathrm{WBC})(/ \mu \mathrm{l})$ & $1190(640-2030)$ & $750(280-1685)$ & $0.017^{*} \beta$ \\
\hline ANC $(/ \mu \mathrm{l})$ & $370(75-930)$ & $20(0-530)$ & $0.001^{*} \beta$ \\
\hline Platelet $(/ \mu \mathrm{l})$ & 34000 & 28000 & $0.018^{*} \beta$ \\
\hline Prohepcidin $(\mathrm{ng} / \mathrm{ml})$ & $(17000-68500)$ & $(14000-46500)$ & $0.979 \alpha$ \\
\hline Hepcidin $(\mathrm{ng} / \mathrm{ml})$ & $167.29 \pm 29.31$ & $167.15 \pm 27.61$ & $0.629 \beta$ \\
\hline CRP $(\mathrm{mg} / \mathrm{dl})$ & $315(293.99-315)$ & $315(314.76-315)$ & $0.0001^{*} \beta$ \\
\hline Procalcitonin & $1.733(0.43-4.06)$ & $6.17(2.42-15.69)$ & 0.005 \\
\hline $\begin{array}{l}{ }^{*} p<0.05 \text { statistically significant; S.D: Standard deviation; } \alpha: \text { Paired samples t-test; } \beta \text { : Wilcoxon signed } \\
\text { rank test. }\end{array}$ & $0.05(0.05-0.05)$ & $0.05(0.05-1)$ & 0.034 \\
\hline
\end{tabular}

During neutropenic fever, WBC (white blood cell) $(p=0.017$ ), absolute neutrophil count $(p<0.001)$ and platelet $(p=0.018)$ were significantly lower than neutropenic period. However, no significant difference was found between the two groups at the hemoglobin level $(p=0.483)$. One cause for this might be that the hemoglobin value has not yet dropped in certain individuals due to the short interval between neutropenia and neutropenic fever. Another possibility is that the patient got erythrocyte transfusions prior to developing neutropenic fever.

In neutropenic fever group, procalcitonin was found significantly higher than neutropenic group (med: $0.05 \mathrm{ng} / \mathrm{ml}$, IQR: $0.05-1 \mathrm{ng} / \mathrm{ml}$ vs. med: $0.05 \mathrm{ng} / \mathrm{ml}$, IQR: $0.05-0.05 \mathrm{ng} / \mathrm{ml} ; p=$ 0.034). CRP was also found to be higher in the neutropenic fever group compared to the neutropenic group (med: $1.733 \mathrm{mg} / \mathrm{dl}$, IQR: 0.43-4.06 mg/dl vs. med: $6.17 \mathrm{mg} / \mathrm{dl}$, IQR: 2.42-15.69 $\mathrm{mg} / \mathrm{dl} ; \mathrm{p}=0.001)$. There was no significant difference in neutropenic fever group in terms of prohepcidin compared to the neutropenic group $(167.15 \pm 27.61 \mathrm{ng} / \mathrm{ml}$ vs. $167.29 \pm$ $29.31 \mathrm{ng} / \mathrm{ml} ; \mathrm{p}=0.979$ ); and there was also no significant difference in neutropenic fever group in terms of hepcidin compared to neutropenic group (med: $315 \mathrm{ng} / \mathrm{ml}$, IQR: $293.99-315 \mathrm{ng} / \mathrm{ml}$ vs. med: $315 \mathrm{ng} / \mathrm{ml}$, IQR: $314.76-315 \mathrm{ng} / \mathrm{ml} ; p=0.629$, Table II). In neutropenic fever group, the correct proportion was found between prohepcidin and hepcidin $(p=0.001 ; r=0.732)$. The neutropenic fever group had a significant correct ratio between CRPand procalcitonin ( $p<0.001 ; r=0.512)$.

There was also no significant difference between the patient's total neutropenic duration and prohepcidin, hepcidin, CRP, ferritin, procalcitonin. There was also no any difference between prohepcidin and hepcidin levels of neutropenic patients with and without chemotherapy.

\section{DISCUSSION}

In present study, including 53 neutropenic patients and 44 healthy individuals, hepcidin and prohepcidin levels were significantly higher in the neutropenic group than in the healthy control group. However, a similar significant difference could not be observed between the neutropenic period and neutropenic fever period. Yeşilbaş et al. found that hepcidin was a good marker in intensive care pediatric patients with sepsis and septic shock compared to the nonseptic intensive care and healthy control groups. ${ }^{16}$ The reason behind the present difference in results may be that the vital signs were mostly stable in the majority of patients during fever in this study. If the levels of hepcidin and prohepcidin were examined during the more severe infection period or in the septic period with unstable vital signs, different results could be obtained. In addition, the 'adult' patient group in this study may be a reason why different results were obtained.

Hepcidin can be found in the blood in mature form or prohormone form. It is thought that the expression of prohepcidin in the liver regulates itself by binding to the HAMP (hepcidin antimicrobial peptide) promoter. ${ }^{9}$ As indicated before, prohepcidin is a critical marker for assessing inflammation. ${ }^{11,12}$ In this study, in addition to serum hepcidin levels, serum prohepcidin levels were also measured. A correct proportion was found between prohepcidin and hepcidin in the neutropenic fever group $(p<0.001 ; r=0.732)$.

It also showed that hepcidin in urine increases in sickle cell anemia and myelodysplasia patients secondary to erythrocyte transfusion. ${ }^{17,18}$ Serum ferritin level also increases with iron loading and inflammation. It was found that serumferritin correlated with the excretion of hepcidin. ${ }^{10}$ Infection and iron levels influence hepcidin synthesis in hepatocytes in an indirect manner. In this study, no significant relationship was found between prohepcidin and iron parameters as ferritin, serum iron level and transferrin saturation in a neutropenic group. Similarly, no significant correlation was found between hepcidin and these iron parameters (Table I). There was also no significant difference between the patient's total neutropenic duration and prohepcidin and also hepcidin. In a study of 100 patients by Akı et al., no significant correlation was found between serum prohepcidin levels and serum iron parameters and interleukin 6 levels in the pretransplant period of hematopoietic stem-cell transplantation (HSCT). However, prohepcidin was found to have a negative correlation with neutropenic fever $(p<0.001)$ and febrile neutropenia days $(p=0.003)$. No 
correlation was found between iron parameters and prohepcidin levels, and survival in the pretransplantation period. ${ }^{14}$

Hepcidin is expected to increase in rheumatic diseases, inflammatory bowel diseases, chronic infections, and multiple myeloma. ${ }^{19}$ In the study, conducted by Sharma et al., it was found that urine hepcidin levels were three times higher than the control group in 44 stage 3 myeloma patients before treatment. It is stated here that IL- 6 dependent and non-IL- 6 dependent mechanisms can be effective. ${ }^{20}$ Pathogenic macromolecules, such as liposaccharides, increase IL- 6 production by acting on macrophages and Kupfer cells. IL-6 also induces hepcidin mRNA production in hepatocytes. ${ }^{10}$ In the present study, there were only 10 multiple myeloma patients. In the future, a study involving more myeloma patients can be planned.

In this study, no significant relationship was found between prohepcidin or hepcidin and hemoglobin, neither in the neutropenic period nor neutropenic fever. In the study of Macciò et al., anemia was detected in $63 \%$ of 888 cancer patients with different stages ${ }^{21}$ In this study, the WBC $(p=0.017)$ absolute neutrophil count $(p=0.0001)$ and platelet values $(p=0.018)$ were found to be significantly lower in the neutropenic fever period compared to the neutropenic period. However, there was no significant difference in hemoglobin level between the two groups ( $p=0.483$ ). There is no significant difference in prohepcidin and hepcidin levels, suggesting that it may be associated with low but stable hemoglobin levels.

The incidence of anemia in solid tumor patients with elevated CRP was linked with hepcidin overexpression in research done by Cheng et al. ${ }^{22}$ CRP was substantially higher in the neutropenic fever group than in the neutropenic group in the present research. Despite this, there was no substantial rise in hepcidin levels. The explanation for this might be that the study patients were diagnosed with hematological malignancy, and hematological cancers implicated additional undiscovered processes.

The main limitation of this study was that patients' hematologic malignancy type was not homogeneous; and for some, the number of patients was insufficient. The majority of the patients' diagnosis was AML.

\section{CONCLUSION}

Hepcidin is thought to be an essential mediator in inflammation. Although there was no significant difference in serum hepcidin and prohepcidin levels between neutropenia and neutropenic fever in patients, higher levels were found in both groups compared to the control group. During the neutropenic fever period; however, no significant increase in hepcidin levels was observed. As a result, it does not appear to be suitable for use in an inflammatory condition such as neutropenic fever.

\section{ETHICALAPPROVAL:}

Ethical approval was granted by the Ethical Committee of Pamukkale University ([2018] 016) prior to initiation of the research work.

\section{PATIENTS' CONSENT:}

Each participant signed a written informed consent form before enrolment. Informed consents were obtained from patients to publish the data concerning this case.

\section{CONFLICT OF INTEREST:}

The authors declared no conflict of interest.

\section{AUTHORS' CONTRIBUTION:}

BUK, EA: Conception or design of the work, or the acquisition, analysis, or interpretation of data for the work, drafting the work or revising it critically for important intellectual content and final approval of the version to be published.

NG, GAC, HS: Acquisition, analysis, or interpretation of data for the work.

\section{REFERENCES}

1. Rivera-Salgado D, Valverde-Muñoz K, Ávila-Agüero ML. Rev Chilena Infectol 2018; 35(1):62-71. doi: 10.4067/s071610182018000100062.

2. Escrihuela-Vidal F, Laporte J, Albasanz-Puig A, Gudiol C. Update on the management of febrile neutropenia in hematologic patients. Rev Esp Quimioter 2019; 32 Suppl 2(Suppl 2):55-58.

3. Kochanek M, Schalk E, Von Bergwelt-Baildon M, Beutel G, Buchheidt D, Hentrich $M$, et al. Management of sepsis in neutropenic cancer patients: 2018 guidelines from the infectious diseases working party (AGIHO) and intensive care working party (iCHOP) of the german society of hematology and medical oncology (DGHO). Ann Hematol 2019; 98(5):1051-1069. doi: 10.1007/s00277-019-03622-0.

4. Muckenthaler MU, Rivella S, Hentze MW, Galy B. A red carpet for iron metabolism. Cell 2017; 168(3):344-361. doi: 10.1016/j.cell.2016.12.034. doi: 10.1016/j.cell.2016.12.034.

5. Haschka D, Hoffmann A, Weiss G. Iron in immune cell function and host defense. Semin Cell Dev Biol 2020; 29:S1084-9521(20)30199-3. doi: 10.1016/j.semcdb.2020. 12.005 .

6. McCullough K, Bolisetty S. iron homeostasis and ferritin in sepsis-associated kidney injury. Nephron 2020; 144(12):616-20. doi: 10.1159/000508857.

7. Camaschella C, Nai A, Silvestri L. Iron metabolism and iron disorders revisited in the hepcidin era. Haematologica 2020; 105(2):260-272. doi:10.3324/ haematol.2019.232124.

8. Saneela S, Iqbal R, Raza A, Qamar MF. Hepcidin: A key regulator of iron. J Pak Med Assoc 2019; 69(8):1170-5.

9. Pandur E, Sipos K, Grama L, Nagy J, Poór VS, Sétáló G, et al. Prohepcidin binds to the HAMP promoter and autoregulates its own expression. Biochem J 2013; 451(2):301-11. doi: 10.1042/BJ20121466.

10. Ganz T. Hepcidin, a keyregulator of iron metabolism and mediator of anemia of inflammation. Blood 2003; 102(3): 783-8. doi: 10.1182/blood-2003-03-0672.

11. Avcı Çiçek E, Rota S, Dursun B, Kavalci E. Evaluation of serum NGAL and hepcidin levels in chronic kidney disease patients. Ren Fail 2016; 38(1):35-9. doi: 10.3109/08860 22X.2015.1107823. 
12. Frazer DM, Anderson GJ. Hepcidin compared with prohepcidin: An absorbing story. Am J Clin Nutr 2009; 89(2):475-6. doi: 10.3945/ajcn.2008.27232.

13. Schranz M, Bakry R, Creus M, Bonn G, Vogel W, Zoller H. Activation and inactivation of the iron hormone hepcidin: Biochemical characterization of prohepcidin cleavage and sequential degradation to $\mathrm{N}$-terminally truncated hepcidin isoforms. Blood Cells Mol Dis 2009; 43(2):169-79. doi: 10.1016/j.bcmd.2009.03.008.

14. Akı SZ, Paşaoğlu H, Yeğin ZA, Suyanı E, Demirtaş CY, Ozkurt ZN, et al. Impact of prohepcidin levels and iron parameters on early post-transplantation toxicities. Hematol 2011; 16(5):284-90. doi: 10.1179/102453311X1 3085644680023.

15. Sow FB, Florence WC, Satoskar AR, Schlesinger LS, Zwilling BS, Lafuse WP. Expression and localisation of hepcidin in macrophages: A role in host defense against tuberculosis. J Leukoc Biol 2007; 82(4):934-45. doi: 10.1189/jlb.0407216.

16. Yeşilbaş O, Şevketoğlu E, Bursal Duramaz B, Kıhtır HS, Gedikbaşı A, Talip Petmezci M, et al. Role of hepcidin in the diagnosis of sepsis and septic shock in children. Turk J Med Sci 2018; 48(3):517-524. doi: 10.3906/sag-1707-120.
17. Nemeth E, Valore EV, Territo M, Schiller G, LichtensteinA, Ganz T. Hepcidin, a putative mediator of anemia of inflammation, is a type II acutephase protein. Blood 2003; 101(7):2461-3. doi: 10.1182/blood-2002-10-3235.

18. Brissot P, Troadec MB, Loréal O, Brissot E. Pathophysiology and classification of iron overload diseases; update 2018. Transfus Clin Biol 2019; 26(1):80-8. doi: 10.1016/j.tracli. 2018.08.006.

19. D'Angelo $\mathrm{G}$. Role of hepcidin in the pathophysiology and diagnosis of anemia. Blood Res 2013; 48(1):10-5. doi: 10.5045/br.2013.48.1.10.

20. Sharma S, Nemeth E, Chen YH, Goodnough J, Huston A, Roodman GD, et al. Involvement of hepcidin in the anemia of multiple myeloma. Clin Cancer Res 2008; 14(11):3262-7. doi: 10.1158/1078-0432.CCR-07-4153.

21. Macciò A, Madeddu C, Gramignano G, Mulas C, Tanca $\mathrm{L}$, Cherchi $\mathrm{MC}$, et al. The role of inflammation, iron, and nutritional status in cancer-related anemia: Results of a large, prospective, observational study. Haematologica 2015; 100(1):124-32. doi: 10.3324/haematol.2014.112813.

22. Cheng Z, Yan M, Lu Y, Pan XT. Expression of serum BMP6 and hepcidin in cancer-related anemia. Hematology 2020; 25(1):134-8. doi: 10.1080/16078454.2020.1738098. 